\title{
IDENTIFIKASI KUALITAS AIR SUMUR WARGA DESA PELANGAN KECAMATAN SEKOTONG YANG TERDAMPAK PENCEMARAN LIMBAH PENGOLAHAN GELONDONG EMAS
}

\author{
Laili Mardiana $^{1 *}$, Alfina T. Alaydrus ${ }^{1}$, Kasnawi Alhadi' ${ }^{1}$, Suhayat Minardi ${ }^{1}$ \\ ${ }_{1}$ Program Studi Fisika/Fakultas Matematika dan IImu Pengetahuan Alam Universitas Mataram \\ *Co-Author :lailimardiana@unram.ac.id
}

\begin{abstract}
ABSTRAK. Terjadi pergeseran keadaan sosial ekonomi masyarakat Desa pelangan dari sisi mata pencaharian, pada awalnya masyarakat bermata pencaharian sebagai nelayan dan Petani kebun, namun keadaannya berubah, masyarakat banyak memilih profesi menjadi penambang emas. Hal ini diakibatkan telah ditemukan sumber emas di wilayah perbukitan sekotong. Keberhasilan Masyarakat dalam mentransformasi kehidupannya menuju perekonomian yang lebih baik bertolak belakang dengan ketidakpedulian masyarakat terhadap keselamatan diri dan lingkungannya. Permasalahan yang terjadi di masyarakat adalah kurangnya kepedulian terhadap lingkungan. Lokasi pembuangan limbah sisa gelondongan yang tercampur dengan zat merkuri sangat dekat dengan lokasi sumursumur warga desa Pelangan. Dikhawatirkan sumur-sumur warga telah tercemar oleh sisa-sisa gelondongan yang mengadung bahan pencemar. Masyarakat juga belum mendapatkan tentang kondisi air pada sumur-sumur mereka. Berdasarkan permasalahan tersebut maka dilakukan pengujian terhadap 8 sumur warga yang memilki tempat pengolahan gelondongan emas. Diambil 8 sampel air sumur dari titik sampel sumur yang sudah ditentukan. dilakukan pengujian kualitas air berdasarkan parameter Daya Hantar Listrik (DHL), Kekeruhan dan suhu. Berdasarkan hasil identifikasi dan interpretasi keadaan air, bahwa kondisi air sumur warga disekitar aktivitas gelondongan dapat dikatakan tercemar. Hal ini diidikasikan oleh nilai konduktivitas listriknya $>500$ us $/ \mathrm{cm}$, tingkat kekeruhan $>5 \mathrm{ntu}$. Pada kondisi ini terliahat bahwa semakin dekat jarak pembuangan limbah dengan sumur maka nilai konduktivitas dan tingkat kekeruhan relatif tinggi.
\end{abstract}

Kata Kunci: sumur galian, tercemar,gelondongan emas

ABSTRACT. There is a shift in socio-economic situation of the community in the Pelangan village of Livelihoods, at first the community as a fisherman and farmer garden, but the circumstances change, the most of the community choose the profession to become gold miners. This is due to the gold source found in the Sekotong hilly area. The success of society in transforming its life towards a better economy is in contradictory to the society's lack awarenessto the self safety and its environment. The problems that occur in the community are a lack of concern for the environment. The waste disposal site of logs mixed with mercury is very close to the location of the wells of the village of Pelangan. Feared the wells of the citizens have been polluted by the remnants of the spindles that contain pollutants. People are also not getting about the water conditions in their wells. Based on the problem, the test was conducted against 8 wells of citizens who had the processing place of gold logs. Taken 8 samples of well water from the pre-determined well sample point. Water quality testing based on electricity power (DHL) parameters, turbidity and temperature. Based on the results of the identification and interpretation of water State, that the condition of the water wells around the logs can be said to be polluted. It is indicated by its electrical conductivity value $>500$ us/cm, turbidity level > $5 \mathrm{ntu}$. In this condition, it is involved that the closer the distance of disposal of waste with the well then the higher conductivity value and turbidity level.

Keyword: Excavation Well, Polutted, Golden Spindle 


\section{PENDAHULUAN}

Sekotong merupakan salah satu kecamatan di Kabupaten Lombok barat NTB yang memiliki potensi sumberdaya alam yang melimpah. sumberdaya alam tersebut meliputi emas, tembaga, dan perak. menurut peta geologi bahwa potensi tambang emas di Sekotong mencapai 1.596 ton dan dapat ditambang selama kurang lebih puluhan tahun. Wilayah sekotong teridnetifikasi memiliki kandungan emas yang memadai, namun tidak dapat dieksploitasi secara resmi karena pemerintah provinsi NTB telah menerbitkan peraturan daerah (perda) nomor 11 tahun 2006 tentang rencana tata ruang wilayah (RTRW) provinsi NTB. Pasal 38 perda nomor 11 tahun 2006 tersebut membatasi persetujuan penambangan yang diterbitkan para bupati di Pulau Lombok. Karena pembatasan inilah yang menyebabkan warga setempat nekat melakukan aktivitas penambangan secara ilegal dengan cara-cara tradisional(www.esdm.go.id). Salah satu Desa yang mlakukan aktivitas ini adalah Desa Pelangan.

Penduduk Desa pelangan kecamatan Sekotong melakukan pengolahan hasil tambang menjadi emas di rumah masingmasing penambang. Proses pengolahan sampai pemisahan sehingga menghasilkan emas murni disebut proses gelondongan. Untuk sampai pada proses menghasilkan emas murni maka dilakukan proses-proses secara kimia yaitu melakukan proses pereaksian dengan zat merkuri/ raksa sebagai zat yang dapat mengikat emas. Proses ini sudah dilakukan sekitar 10 tahun dan telah menggunakan merkuri lebih dari 70 ton per tahun. Pembuangan air sisa pengolahan dibuang pada galian yang dibuat manual. Sehingga dikhawatirkan bahwa terjadinya perembesan air pada tanah dan berdampak terhadap tercemarnya sumur galian disekitar wilayah tersebut. dan terdapat kandungan merkuri pada air sumur tersebut.

Masyarakat Desa Pelangan masih menggunakan sumur galian sebagai sumber air untuk pemenuhan kebutuhan seharihari untuk memasak, mandi dan mencuci. Hal ini sangat kontradiktif bahwa jika zat merkuri yang terpapar secara langsung maupun tidak langsung dapat mengganggu kesehatan manusia dan mikroorganisme di lingkungan. Seperti gangguan imunologis, Emboli Paru, kematian dalam kandungan dan lain-lain (ik.pom.go.id) Oleh Karena itu perlu dilakukan identifikasi kualitas airsumur galian warga berdasarkan parameter Daya Hantar Listrik dan Kekeruhan.

\section{ANALISIS PERMASALAHAN}

Berdasarkan hasil observasi awal terhadap kondisi riil daerah Pelangan maka dapat dijabarkan permasalahan yang dihadapi yaitu sebagai berikut: Lokasi pembuangan limbah sisa gelondongan yang tercampur dengan zat merkuri sangat dekat dengan lokasi sumur-sumur warga desa Pelangan. Dikhawatirkan sumur-sumur warga telah tercemar oleh sisasisa gelondongan yang mengadung bahan pencemar. Belum adanya informasi kepada masyarakat tentang kondisi air pada sumur-sumur yang merupakan kebutuhan pokok mereka yang diindikasikan sudah tercemar akibat aktivitas masyarakat pada proses gelondongan emas. Masyarakat masih beranggapan dan seolah-olah bahwa kondisi lingkungan dan sumberdaya air mereka masih baik-baik saja. hal ini kontradiktif terhadap kondisi real bahwa kemungkinan besar bahwa sumberdaya air yang mereka gunakan sudah tercemar.Maka dipandang perlu untuk dilakukan proses identifikasi kualitas air setiap sumur-sumur warga masyarakat daerah Pelangan kecamatan Sekotong, selanjutnya akan dilakukan sosialisasi kepada warga masyarakat tentang kondisi air pada sumur-sumur warga, teknik pengelolaan limbah serta pemberian solusi yaitu teknik mengatasi jika sumur warga sudah tercemar.

\section{SOLUSI YANG DITAWARKAN}

Berdasarkan uraian permasalahan yang dihadapi mitra, maka solusi yang ditawarkan dapat dijabarkan dalam 4 tahap. Tahap 1 dilakukan survey kondisi Lingkungan secara langsung seperti yang ditunjukkan pada gambar 1. Dilakukan penentuan titik pengambilan sampel dan pengukuran jarak sumur dengan tempat pembuangan limbah. 


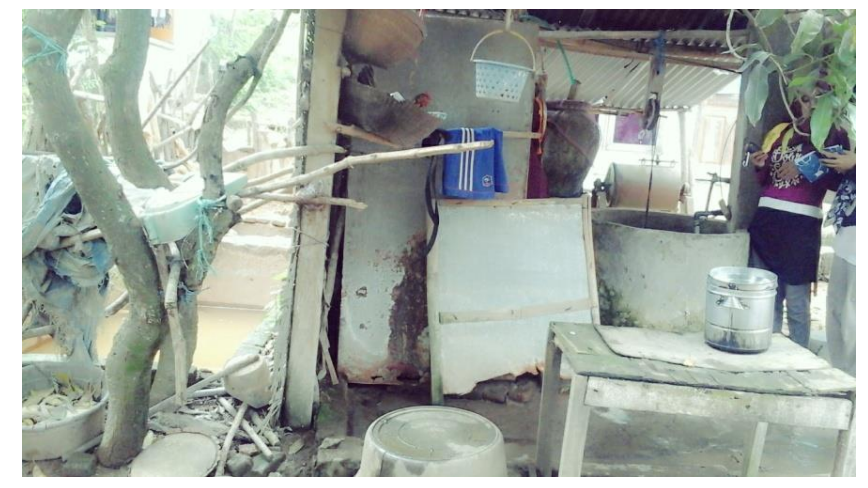

Gambar 1. Survey lokasi pengambilan sampel dan pengukuran jarak sumur dengan pembuangan

Tahap kedua dilakukan pengambilan sampel air sumur. Di ambil 8 titik pengambilan sampel. Sampel tersebut dimasukkan dalam botol steril untuk siap-siap dilakukan pengujian. Tahap ketiga yaitu pengujian sampel berdasarkan dua parameter yaitu Daya Hantar Listrik dan Turbiditas. selanjutnya dilakukan analisis nilai hasil pengukuran untuk penentuan kategori kondisi sumur. Hasil pengujian kemudian disosialisasikan kepada mayarakat setempat seperti yang ditunjukkan pada gambar 2.

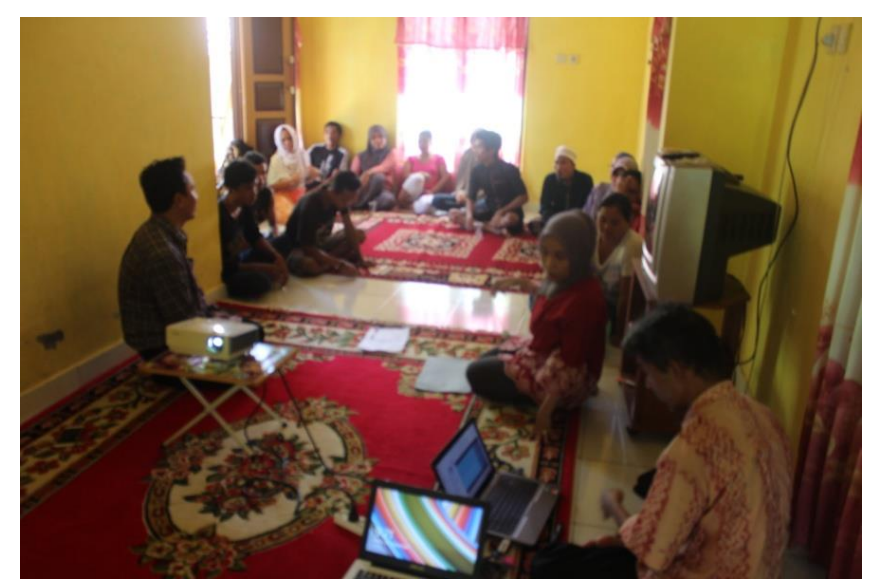

Gambar 2. Sosialisasi Hasil pengujian kualitas air sumur

\section{HASIL DAN PEMBAHASAN}

Telah dilakukan pengujian kualitas air sumur warga di Desa Pelangan Kecamatan Sekotong Kabupaten Lombok Barat, yaitu yang terindikasi tercemar akibat aktivitas gelondongan emas. Terdapat 8 titik pengambilan sampel air sumur warga. Dilakukan juga pengukuran jarak antara sumur dengan lokasi pembuangan Limbah. Hal ini dilakukan agar dapat diketahui pengaruh jarak sumur dengan lokasi pembuangan limbah sisa gelonongn emas terhadap nilai parameter DHL, kekeruhan dan suhu. Berdasarkan hasil pengujian 3 parameter dimaksud maka diperoleh sebaran masing masing nilai seperti yang ditunjukkan pada gambar $3,4,5$ 


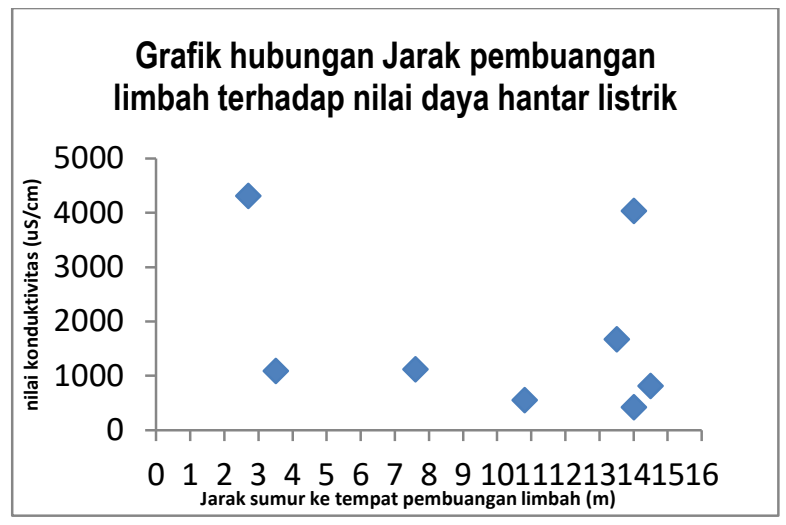

Gambar 3. hubungan Jarak pembuangan limbah terhadap nilai daya hantar listrik.

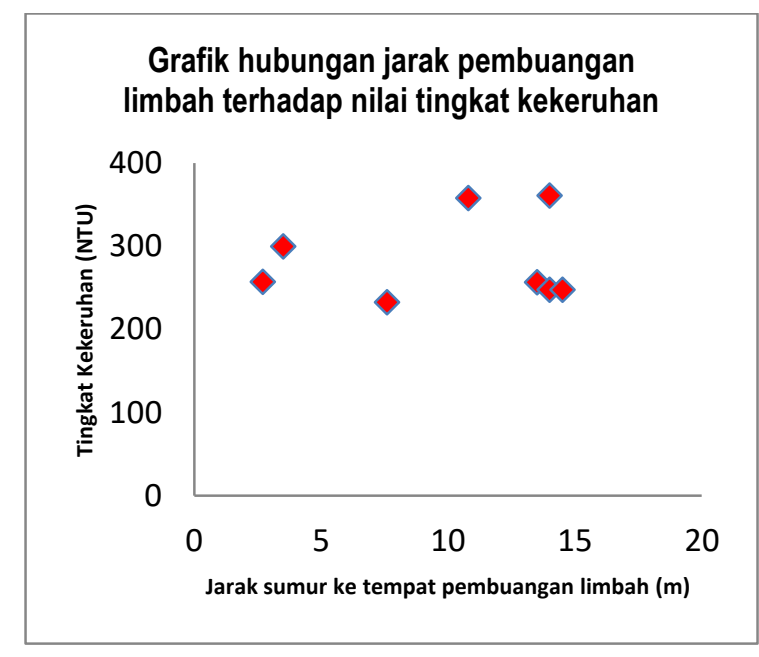

Gambar 4. Hasil pengukuran nilai tingkat kekeruhan pada 8 titik pada wilayah yang terindikasi tercemar akibat aktivitas gelondongan emas

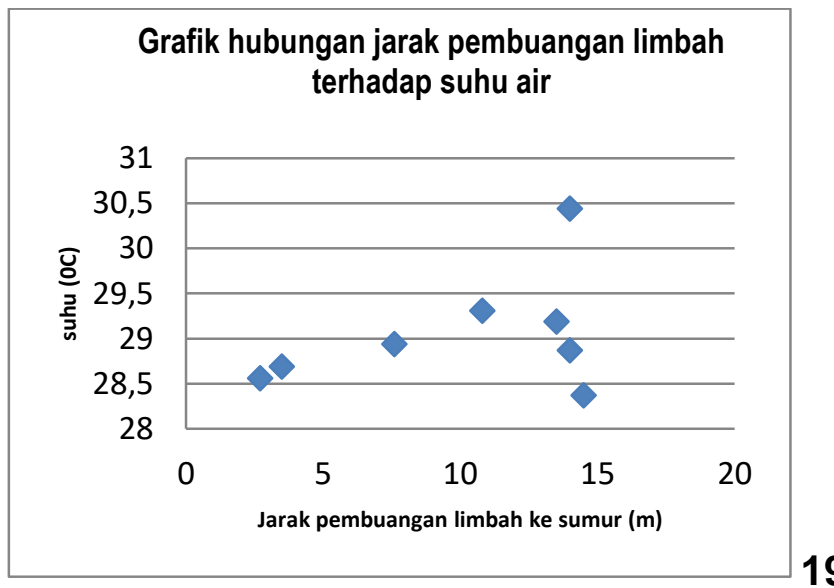

Gambar 5. Hasil pengukuran nilai tingkat kekeruhan pada 8 titik pada wilayah yang terindikasi tercemar akibat aktivitas gelondongan emas 
Nilai DHL sangat dipengaruhi oleh konsentrasi ion dalam air. Kemampuan air menghantarkan arus listrik ditentukan oleh kadar ion didalamnya dan temperatur air. Kadar ion dalam air akan mempercepat hantaran elektron listrik yang dilaluinya dan semakin tinggi temperatur air maka semakin mudah gerakan ion, sehingga semakin mempercepat perpindahan elektron. Oleh karena itu perhitungan nilai DHL harus distandarkan pada temperatur tertentu, yaitu $25^{\circ} \mathrm{C}$. Nilai $\mathrm{DHL}$ akan meningkat jika temperatur bertambah tinggi. Peningkatan nilai DHL juga disebabkan adanya material tersuspensi atau terlarut dalam air.Kondisi ini sagat erat hubungannya dengan kandungan merkuri yang dibawa oleh rembesan air tanah sehingga mencemari air sumur. Sifat merkuri yang tidak menguap namun mengendap berdampak terhadap peningkatan nilai DHL. Semakin banyak padatan terlarut, maka semakin tinggi nilai DHL. Hal inilah yang terlihat dari hasil pengukuran di daerah Pelangan yang nilai DHLnya $>500$ us/cm.

Kategori dan skor untuk penilaian indikator tingkat kandungan pencemar untuk parameter fisika berdasarkan Peraturan Direktur Jenderal Rehabilitasi Lahan dan Perhutanan Sosial Nomor : P.04/N-Set/2009. Berdasarkan hasil identifikasi dan interpretasi keadaan air, bahwa kondisi air sumur warga disekitar aktivitas gelondongan dapat dikatakan tercemar. Hal ini diidikasikan oleh nilai konduktivitas listriknya $>500 \mathrm{us} / \mathrm{cm}$, tingkat kekeruhan $>5 \mathrm{ntu}$. Pada kondisi ini terliahat bahwa semakin dekat jarak pembuangan limbah dengan sumur maka nilai konduktivitas dan tingkat kekeruhan relatif tinggi.

\section{KESIMPULAN}

Berdasarkan hasil identifikasi dan interpretasi keadaan sampel air sumur warga di Desa Pelangan dapat disimpulkan bahwa kondisi air sumur warga disekitar aktivitas gelondongan tercemar. Hal ini diidikasikan oleh nilai konduktivitas listriknya $>500$ us/cm, tingkat kekeruhan $>5$ ntu. Pada kondisi ini terlihat bahwa semakin dekat jarak pembuangan limbah dengan sumur maka nilai konduktivitas dan tingkat kekeruhan relatif tinggi.

\section{UCAPAN TERIMA KASIH}

Lembaga Penelitian dan Pengabdian kepada masyarakat melalui dana BOPTN tahun 2018

\section{REFERENSI}

Gunamantha, I Made. 2012. Buku Ajar Analisis Air. Singaraja : Undiksa Press.

Haryanto, Tri. 2008. Pencemaran Lingkungan. Klaten : Cempaka Putih.

Linsley Jr, Ray K, Max A. Kohler, dan Joseph L. H. Paulhus. 1996. Hidrologi Untuk Insinyur. Jakarta : Erlangga.

http://www.esdm.go.id.

http://ik.pom.go.id/Artikel/Merkuri. Diakses Agustus 2018. 